\title{
Światy wartości mieszkańców miasta. Na przykładzie badań socjologicznych w Zabrzu
}

\section{Nota}

М/środowisku Uniwersytetu Śląskiego w Katowicach, z inicjatywy historyka, prof. Antoniego Barciaka, realizowany jest projekt multidyscyplinarnych monografii miast Metropolii Śląsko-Zagłębiowskiej, z wyodrębnioną obszerną częścią socjologiczną. W roku 2012 ukazało się dwutomowe dzieło poświęcone Katowicom, a w roku 2016 - Sosnowcowi ${ }^{1}$. Obecnie trwają prace nad przygotowaniem do druku monografii dotyczącej Zabrza. W socjologicznej jej części uwzględniana jest między innymi problematyka orientacji na wartości mieszkańców badanych miast, co znajduje odzwierciedlenie w tytułach rozdziałów wspomnianych monografii ${ }^{2}$.

Projekt socjologicznych badań terenowych związanych z monografią Zabrza został zrealizowany metodą wywiadów kwestionariuszowych w latach

* Prof. DR Hab. Wojciech Krzysztof ŚwiąTKIEWICZ - Uniwersytet Śląski w Katowicach, Univerzita Konštantina Filozofa v Nitre, email: wojciech.swiatkiewicz@us.edu.pl,wswiatkiewicz@ ukf.sk ORCID: 000-0002-8459-5114.

${ }^{1}$ Katowice. Środowisko, dzieje, kultura, język i społeczeństwo. T. 1-2, A. Barciak, E. Chojecka, S. Fertacz (red.), Katowice 2012; Sosnowiec. Obraz miasta i jego dzieje. T. 1-2, A. Barciak, A. T. Jankowski (red.), Sosnowiec 2016.

${ }^{2}$ Dla przykładu w tomie 2, w części 7 monografii o Sosnowcu, zatytułowanej „Współczesny obraz miasta i jego mieszkańców”, znajduje się rozdział noszący tytuł „Orientacje na wartości - między sacrum i profanum”, który zawiera m.in. artykuły: Justyna Kijonka, „Praca i wzory konsumpcji”; Andrzej Górny, „Czas wolny”; Wojciech Świątkiewicz, „Religijność w przestrzeni kulturowej miasta”. Podobnie w monografii Katowic, w tomie 2 w części 8, noszącej tytuł „Orientacje na wartości - między sacrum i profanum”, znajdują się m.in. artykuły: Andrzej Kasperek, „Praca i wzory konsumpcji”; Andrzej Górny, „Czas wolny”; Wojciech Świątkiewicz, „Sacrum i jego światy”. 
2018-2019. Zbiorowość badana, dobrana wedle kryteriów celowo-losowych, uwzględniających płeć i wiek respondentów, obejmowała 323 osoby mieszkające $\mathrm{w}$ różnych dzielnicach miasta. Wyniki badań empirycznych, przedstawiane $\mathrm{w}$ tym artykule, stanowią fragment szerszego opracowania przygotowanego dla monografii miasta.

\section{Wartości w perspektywie socjologicznej}

Wartości należą do porządku kultury i stanowią fundamenty życia społecznego. Poprzez ich internalizację w postawy i zachowania, w praktyki życia społecznego ludzi kształtują profile kulturowe zarówno całych społeczności jak i osobowości społecznych poszczególnych jednostek. W realizowaniu powinności aksjologicznego uczestnictwa Władysław Stróżewski dostrzega sens ludzkiego życia oraz istotę człowieczeństwa‥ Komentując filozofię wartości Stróżewskiego, Marek Rembierz zwraca uwagę na ponadkulturowe wymiary prawdy, dobra i piękna, ujmowane jako wartości wspólne oraz uniwersalne, a także na rozróżnienie wartości pełnych i niepełnych ${ }^{2}$.

„Pełne [...] wystarczają do całkowitego i pozytywnego wypełnienia całej dziedziny ich realizacji, [...] niepełne nie odznaczają się tą właściwością. Większość wartości należy do grupy drugiej. Ich niewystarczalność polega na tym, że im bardziej się [...] realizują, tym bardziej dopuszczają paralelną realizację wartości negatywnych [...]. Zapobiec temu można jedynie przez pozostawienie ich w stanie [...] niedopełnienia i otwarcia [...] [na] wartości pozytywne, które mogą [...] je uzupełniać. Takimi wartościami [...] niepełnymi są wolność, sprawiedliwość i wiele innych; [...] dopuszczają [one] jako dookreślenie ich charakterystyki przymiotnik "prawdziwe«: prawdziwa wolność, prawdziwa sprawiedliwość, [...]; możliwa jest nieprawdziwa wolność, nieprawdziwa sprawiedliwość [...]. W celu zapobiegania zwyrodnieniu wartości niepełnych należy w praktyce dążyć do realizacji odpowiednich wartości wobec nich komplementarnych"3.

Świat społeczny jest determinowany aksjologicznie, a jednocześnie otwarty na nowe rozumienie i doświadczenie wartości. Człowiek na drodze podejmowanych przez sobie działań kształtuje swoją obecność w świecie kultury, która jest

${ }^{1}$ Cz. Piecuch: Stróżewski Władysław Antoni, [w]: Encyklopedia Filozofii Polskiej. Polskie Towarzystwo Tomasza z Akwinu, A. Maryniarczyk (red.), online: http://www.ptta.pl/efp/pdf/s/strozewskiw. pdf [dostęp: 4.08.2020].

${ }^{2}$ M. Rembierz, Edukacja międzykulturowa jako ćwiczenie duchowe. Pedagogiczne wymiary kształtowania kultury duchowej i rozumienia wartości ponadkulturowych w kontekście zróżnicowania religijnego i pluralizmu światopoglądowego, „Edukacja Międzykulturowa” 2018, nr 2 (9), s. 117.

${ }^{3}$ W. Stróżewski, Ponadkulturowe wymiary dobra, prawdy i piękna, [w:] tenże, Logos, wartość, miłość, Kraków 2013, s. 361-388. 
„kultem wartości”", odnosząc swoje „ja”, subiektywnie przeżywaną tożsamość, do idei człowieczeństwa zapisanego w języku kultury.

Społeczności tworzą się wokół wspólnoty wartości i ze względu na nie przybierają konkretne postacie, takie jak na przykład naród, państwo, Kościół, rodzina, regiony kulturowe, miasta, partie polityczne, wspólnoty wyznaniowe. Profile kulturowe osobowości społecznej jednostek są konsekwencją internalizacji świata wartości w indywidualnie konstruowane i realizowane projekty życia społecznego.

Podobnie, jak w stosunku do rozumienia kultury, także i wobec pojęcia wartość istnieje wiele rozmaitych określeń wynikających z perspektyw filozoficznych, teoretycznych, metodologicznych, czy praktycznych, które przyjmowane są w podejmowanych analizach. „Gdy mówimy, że coś dla nas jest wartością, chcemy podkreślić, że ten przedmiot w naszym przekonaniu powinien być uznany za wartość (wartości uznawane) lub, że jest on istotnie atrakcyjny dla nas, odczuwany jako wartość, jako coś pożądanego (wartości odczuwane)"5.

"Wartości nadają sens każdemu obszarowi i aspektowi życia ludzkiego. Niezliczone działania, decyzje i wybory, jakie ludzie codziennie podejmują, zależą od wartości, które za nimi stoją. To wartości nadają sens i znaczenie ludzkim działaniom, zachowaniom i wyborom. Wartości są fundamentem życia społecznego. Wartości są filarami zarówno jednostkowego, jak i wspólnotowego życia człowieka"6.

Do kanonu fundamentalnych wartości zalicza się: godność, lojalność, miłość, odpowiedzialność, pracowitość, prawość, przyjaźń, przyzwoitość, solidarność, sprawiedliwość, szacunek, uczciwość, wolność, wrażliwość, współpraca, zaufanie, życzliwość, wdzięczność. Za Romanem Ingardenem możemy dopisać regułę „dobrych wartości”: „Jeżeli nasze dzieła są wysokowartościowe, szlachetne, mądre, dobre, piękne, to i my przez nie dobrzejemy, ale jeżeli noszą w sobie ślady zła, szpetoty, niemocy, choroby lub obłędu, to i my stajemy się ubożsi, słabsi, chorzy" .

W ujęciu socjologicznym, które jest wiodące w przyjętej przez mnie perspektywie teoretycznej i metodologicznej, wyraźnie akcentuje się status ontologiczny wartości, wyrastający z ich przynależności do świata kultury. W klasycznej już definicji kultury, wypracowanej przez Stefana Czarnowskiego, podkreśla się, że tworzy ją całokształt zobiektywizowanych elementów dorobku społecznego, który z racji swej obiektywizacji może rozpowszechniać się w przestrzeni

${ }^{4}$ Bogate swoją aksjosemantyczną pojemnością pojęcie zaczerpnąłem z książki Andrzeja Tyszki pt. Kultura jest kultem wartości. Aksjologia społeczna - studia i szkice, Komorów 1999.

${ }^{5}$ J. Mariański, Wartości uroczyste w świadomości maturzystów puławskich w latach 1994-2009-2016, „Uniwersyteckie Czasopismo Socjologiczne” 2018, nr 23, s. 9.

${ }^{6}$ Fundamenty dobrego społeczeństwa. Wartości, M. Bogunia-Borowska (red.), Kraków 2015, s. 23.

7 R. Ingarden, Książeczka o człowieku, Kraków 1987, s. 36. 
i czasie ${ }^{8}$. To, co jest zobiektywizowane, czyli utrwalone, ponieważ napisane, namalowane, wyrzeźbione, zbudowane, zapamiętane, etc., jest intersubiektywnie dostępne i podlega upowszechnieniu w porządku diachronicznym i synchronicznym. Zobiektywizowanie poprzedzone jest procesami eksternalizacji, czyli uzewnętrzniania ludzkich aktywności intelektualnych czy emocjonalnych, będącej konsekwencją relacji społecznych. Peter L. Berger i Thomas Luckmann, do których koncepcji tu nawiązuję, eksternalizację opisują odwołując się do antropologicznej konieczności ${ }^{9}$. To, co zobiektywizowane, jest społeczne generowane, stanowiąc pewną normatywną potencjalność aktualizującą się w praktykach życia społecznego poprzez procesy pierwotnej i wtórnej socjalizacji, wychowania i kulturalizacji.

W niektórych określeniach kultury zwraca się uwagę na to, że jest ona rzeczywistością sui generis, kierującą się własnymi regułami i prawami. Zobiektywizowane wytwory ludzkiej aktywności - wartości, normy, symbole, wzorce zachowań - podlegają procesom mobilności kultury, aktualizując się w określonych i specyficznych kontekstach społecznej rzeczywistości, które nadają im lokalna postać, definiują społeczne role i funkcje, a ponadto modelują style życia tych, którzy żyją w świecie społecznym objętym kulturowymi wartościami. Wartości legitymizują standardy tego, co jest godne wyboru i preferencji, i „przyczyniają się nie tylko do solidarności społecznej w wymiarach całościowego społeczeństwa (umacnianie trwania i działania systemu społecznego), ale i do szczęścia jednostek, znalezienia sensu życia i bycia człowiekiem"10.

\section{Orientacje na wartości}

Jednym z najczęściej wymienianych czynników, które w świadomości społecznej traktowane są jako okoliczności modelujące indywidualne projekty życia, są przesłanki materialne mierzone ilością posiadanych pieniędzy. W potocznych wyjaśnieniach i tłumaczeniach podejmowanych wyborów życiowych dobrze zadomowionych w praktykach językowych życia codziennego z łatwością można napotkać odwołania do skali posiadanych - albo częściej - nieposiadanych pieniędzy: „Gdybym był bogaczem...., śpiewa Tewje Mleczarz w popularnym musicalu „Skrzypek na dachu”. Posiadanie dużej, wymarzonej ilości pieniędzy, albo przynajmniej „większej kwoty pieniędzy” pozostających do własnej dyspozycji jest traktowane jako czynnik, który daje swobodę w kształtowaniu realizowanych stylów życia, czyli aktualizowanych w praktyce, cenionych i uznawanych wartości.

${ }^{8}$ S. Czarnowski, Kultura. Dzieła. T. 1, Warszawa 1956, s. 20.

9 P.L. Berger, T. Luckmann, Społeczne tworzenie rzeczywistości, przeł. J. Niżnik, Warszawa 1983.

${ }^{10}$ J. Mariański, Socjologia i moralność. Czym jest i dokąd zmierza socjologia moralności, Toruń 2019, s. 209. 
Rzeczywiste czy tylko projektowane wydatkowanie posiadanych funduszy wiąże się z osobistymi hierarchiami wartości, które leżą u podstaw podejmowanych decyzji lub definiują ich cele. Na tej podstawie można rekonstruować hierarchie uznawanych wartości, wyrażające się nie tylko poprzez ich deklaratywny wymiar (wartości explicite), ale także na drodze analizy wskaźników pośrednich (wartości implicite). W badaniach, których wyniki prezentuję, skupiamy się na wybranych aspektach wyborów i decyzji życiowych, które tworzą przesłanki pozwalające na rekonstrukcję hierachii uznawanych wartości w ich powiązaniu z posiadanymi środkami materialnymi. Zakres tematyczny postawionego pytania nie jest zbyt szeroki, ale i na tej podstawie można podjąć próbę charakterystyki orientacji na wartości wśród badanych mieszkańców Zabrza, co pokazują dane zamieszczone w Tabeli 1.

Tabela 1. Deklarowane wartości w powiązaniu ze środkami finansowymi

\begin{tabular}{|c|c|c|}
\hline Na co przeznaczył(a)by P. dodatkową, większą kwotę pieniędzy? & Liczby & Odsetki \\
\hline Ulokował(a)bym na koncie w banku & 111 & 34.58 \\
\hline Założył(a)bym własny interes & 63 & 19.63 \\
\hline Spożytkował(a)bym na kupno luksusowych rzeczy & 55 & 17.13 \\
\hline Spożytkował(a)bym inaczej & 50 & 15.58 \\
\hline Przeznaczył(a)bym na podwyższenie własnych kwalifikacji. & 27 & 8.41 \\
\hline Zainwestował(a)bym na giełdzie & 15 & 4.67 \\
\hline Razem & 321 & $100 \%$ \\
\hline
\end{tabular}

Żródło: badania własne, prowadzone wśród mieszkańców Zabrza

Jak widać z rozkładu danych zamieszczonych w Tabeli 1, ponad jedna trzecia badanych zdecydowałaby się na ulokowanie dodatkowej większej kwoty pieniędzy w banku. Można zapewne na różny sposób interpretować taki wynik odpowiedzi, wskazując między innymi na wartość zaufania, jakim obdarzany jest system bankowy w Polsce. Tłem takich decyzji może być też pozytywna ocena rozwoju gospodarczego i jego stabilności. Ulokowanie własnych pieniędzy na koncie w banku jest również konsekwencją wyborów aksjologicznych cechujących się podążaniem drogą pewną, sprawdzoną, znaną, oswojoną, unikającą ryzyka towarzyszącego indywidualnym decyzjom inwestycyjnym. Jedna piąta badanych $(19.63 \%)$ to ludzie skłonni do podejmowanie indywidualnych decyzji gospodarczych, mający pomysł na pomnażanie pieniędzy (wartości), poprzez rozwój gospodarczy. Można im przypisać także te wartości, które wiążą się z sylwetką człowieka przedsiębiorczego, innowacyjnego, trafnie odczytującego oczekiwania nowoczesności, biorącego los własnego 
życia „we własne ręce”. Na trzecim miejscu lokują się decyzje bezpośrednio konsumpcyjne, których symbolem są „luksusowe rzeczy” (17.13\%). Orientacja na konsumpcję - jako wartość ilustrowaną dążeniem do posiadania „luksusowych towarów” - jest często traktowana jako sygnatura współczesnej kultury, którą opisuje się też jako cywilizację konsumpcji. Pomijając kwestie relatywności i różnorodności sposobów definiowania „luksusowych rzeczy” w różnych środowiskach kulturowych i strukturach społecznych, widzimy że orientacja na konsumpcję jako wartość orientującą style życia nie jest jakąś szczególnie wyróżniającą cechą badanej społeczności, chociaż oczywiście i w niej występuje. Zdecydowanie rzadziej posiadanie większej kwoty dodatkowych pieniędzy inspiruje mieszkańców miasta do wyborów powiązanych z podnoszeniem własnego kapitału wiedzy, kompetencji i umiejętności (8.41\%) oraz podejmowania decyzji opatrzonej wysokim poziomem ryzyka, czyli ,inwestycji giełdowych". Zwłaszcza stosunkowo mały odsetek osób gotowych finansować z własnych funduszy pomnażanie osobistego kapitału intelektualnego poprzez uczestnictwo w szkoleniach czy studiach może rodzić wiele pytań wskazujących na opinie o instytucjach kształcenia czy na indywidualne orientacje na wartości, wśród których wiedza nabywana w systemie studiów i szkoleń nie jest wysoko ceniona.

Struktura wyborów aksjologicznych, bezpośrednio inspirowanych posiadanymi „dodatkowymi” środkami finansowymi, charakteryzujących badanych mieszkańców Zabrza, zdaje się wskazywać na dominację postaw, które można określić obywatelskim aktywizmem, ugruntowanym perspektywą „dnia jutrzejszego", myślenia o lepszej przyszłości budowanej na decyzjach o oszczędzaniu, aktywności gospodarczej, inwestowaniu, rzadziej podnoszeniu własnych kwalifikacji pozwalających na lepsze alokacje w strukturach życia gospodarczego i społeczno-kulturowego. W ten nurt profilu aksjologicznego można też włączyć bardzo rozproszone tematycznie i nacechowane detalicznością wskazań odpowiedzi opisane kategorią „spożytkowałbym w inny sposób” (15.58\%). Między deklarowanymi wartościami a sposobami ich aktualizacji w praktykach życia codziennego nie ma oczywiście prostego i jednoznacznego przejścia, ale określone profile aksjologiczne jednostkowych osobowości są uzasadnioną przesłanką prognozującą kierunki rozwoju życia społecznego. Wiele przykładów ze świata gospodarki wskazuje na to, że profile aksjologiczne osobowości społecznych są czynnikami istotnie wpływającymi na kierunki przeobrażeń, zarówno prowadzących ku destrukcji ładu społecznego, jak i w kierunku dynamizacji wartości w rozmaitych ich odsłonach. Ilustracją mogą być najnowsze losy amerykańskiego miasta Detroit ${ }^{11}$ czy inicjatywy przeobrażeń struktur spo-

${ }^{11}$ J. Dziedzina, Cuda $z$ Michigan, online: https://www.gosc.pl/doc/5727342.Cuda-z-Michigan [dostęp: 5 września 2019]. Tekst komentuje sposoby radzenia sobie z kryzysem miasta Detroit 
łecznych i wizerunku miasta, znane w literaturze pod hasłem „efekt Bilbao”12. To człowiek i jego świat wartości w ostateczności rozstrzyga o pomyślności albo niepowodzeniach w życiu osobistym i własnego środowiska.

Interesująco pod względem socjologicznym rozkładają się preferencje wyborów aksjologicznych uzasadnianych posiadaniem środków finansowych w zależności od płci, wieku i wykształcenia. Zaufanie do banków i wybór wartości „sprawdzonych" są mniej więcej równo podzielane wśród mężczyzn i kobiet, którzy wybierają "tradycyjne” formy oszczędności, przesuwając na instytucje bankowe ciężar podejmowania decyzji i odpowiedzialności. Natomiast najbardziej różnicuje ze względu na kryterium płci orientacja na indywidualną inicjatywę gospodarczą, którą wybiera 71.4\% mężczyzn i „tylko” 28.6\% kobiet. Kobiety natomiast zdecydowanie wyżej niż mężczyźni cenią wartości związane z podnoszeniem kapitału wiedzy, kompetencji i umiejętności. Na podwyższenie własnych kwalifikacji przeznaczyłoby swoje dochody 63\% kobiet i „tylko” 37\% mężczyzn. Interesujące jest również to, że kobiety częściej (63.6\%) niż mężczyźni (36.4\%) spożytkowałyby dodatkowe pieniądze na zakup luksusowych rzeczy. „Towar luksusowy”, traktowany jako wskaźnik statusu społecznego czy prestiżu, zdaje się odgrywać bardziej znaczącą funkcję ornamentacyjną w środowisku kobiet niż mężczyzn.

Wybory aksjologiczne powiązane $\mathrm{z}$ indywidualną aktywnością, innowacyjnością, gotowością podejmowania ryzyka są najwyższe w środowisku ludzi młodych, co w naszych badaniach oznacza tych, którzy nie mają więcej niż 35 lat. Właśnie wśród tej kategorii wiekowej zdecydowanie najwięcej jest osób deklarujących gotowość inwestowania we własny kapitał intelektualny (66.7\%) oraz podjęcia inicjatywy gospodarczej (50.8\%). To dobrze rokuje w perspektywie rozwoju społecznego i gospodarczego miasta. W komentarzu do wyników

jednoznacznie wskazując na znaczenie profili aksjologicznych mieszkańców miasta na drodze pokonywania kryzysu miasta.

${ }^{12}$ Lokalne władze próbowały przeciwdziałać kryzysowi, zmieniając ośrodek przemysłowy w kulturalne centrum regionu, wykorzystując do tego architekturę współczesną. Kluczowe było znalezienie nowego pomysłu na miasto. W Bilbao powstawać zaczęły architektoniczne bryły projektowane przez gwiazdy architektury współczesnej, między innymi efektowne stacje nowej linii metra projektu Normana Fostera i kładka dla pieszych Santiago Calatravy. Przełomowe znaczenie miała kolejna inwestycja, uznawana za jeden z najlepszych przykładów partnerstwa publiczno-prywatnego w historii współczesnej architektury. Ok. 1994 roku wizjonerski stararchitekt Frank Gehry zaprojektował tam Muzeum Guggenheima, które zmieniło to niepozorne miasto w światowe centrum sztuki współczesnej. Odtąd miasto zaczęło tętnić życiem i stało się centrum turystycznym - samo muzeum przyciąga rocznie milion turystów. Muzeum przyczyniło się zatem to powstania wielu nowych miejsc pracy w sektorze usług, od noclegów po restauracje, co wzbogaciło gospodarkę miasta. Dzięki tej zmianie, która wywołała spektakularny efekt, powstał nowy fenomen społeczny nazwany Efektem Bilbao. Zob. Efekt Bilbao. Encyklopedia Architektury, online: https://archirama.muratorplus.pl/encyklopedia-architektury/ efekt-bilbao,62_3345.html [dostęp: 12 września 2019]. Zob. też: Ł. Afeltowicz, J. Gądecki, K. Olechnicki, T. Szlendak, M. Wróblewski, Efekt Bilbao / kult cargo. Nowe instytucje kultury w Polsce, Elbląg 2018. 
podobnego pytania postawionego w badaniach prowadzonych w Katowicach Jan Burzyński konkluduje: „człowiek przedsiębiorczy i pracowity wpisuje się w sylwetkę osobowości nowoczesnego człowieka wyczynu. Jednocześnie cechy te - w połączeniu z wyższym wykształceniem oraz posiadaniem umiejętności abstrakcyjnego myślenia i zdolności specjalistycznych - stanowią o wykrystalizowaniu się osobowości społecznej, charakterystycznej dla przedstawicieli tzw. nowej klasy średniej, warstwy niezależnych specjalistów, których praca zawodowa opiera się na gotowości do „sprzedawania” swojej wiedzy i wysokich kwalifikacji. [...] Jednym z najistotniejszych elementów konstrukcji psychicznej człowieka nowoczesnego jest gotowość do podejmowania ryzyka, która jest postrzegana jako stała cecha przynależna do sfery dyspozycji osobowościowych charakteryzujących działającą jednostkę"13.

\section{Aksjologiczne identyfikacje}

Choć sposób i ukierunkowanie dysponowania środkami finansowymi są ściśle powiązane $\mathrm{z}$ osobistą hierarchią wartości, refleksja nad charakterystyką profilu aksjologicznego jednostki nie może ograniczać się do wymiaru posiadanych przez nią zasobów finansowych. Profil aksjologiczny każdego człowieka jest znacznie bogatszy i obejmuje także te sfery wartości, które nie sprowadzają się do wymiarów materialnych, gospodarczych, a tym bardziej finansowych, i które cechuje także autoteliczność doświadczeń lokowanych w przestrzeniach życia duchowego. Wśród nich fundamentalną rolę odgrywa godność człowieka.

„Godność jest nie tylko cechą zdobiącą człowieka, lecz wyraża istotę człowieczeństwa, skłania ku doskonaleniu umiejętności i cech charakteru, wierności sobie, realizacji postawionych celów, krótko mówiąc, do ciągłego podnoszenia poziomu moralnego. Wysoka ocena szacunku dla samego siebie i wartości drugiego człowieka zakłada, że ludzie będą zdolni wykraczać poza sprawy związane z własnym interesem doceniać także wartości prospołeczne. Człowiek godny, opierający swoją godność na zobiektywizowanych kryteriach moralnych, jest zdolny przeciwdziałać niewłaściwym stosunkom społecznym. [...] Godność, nawet rozumiana w sensie postulatywnym, skłaniać może ludzi do refleksji nad tym, co powinno być, a co jest w rzeczywistości"14.

W takim kontekście możemy też spojrzeć na prezentację wyników odpowiedzi respondentów na pytanie o hierarchię wybranych przykładów wartości.

${ }_{13}$ J. Burzyński, Nowoczesny katowiczanin, [w:] Katowice. Środowisko, dzieje kultura, język i społeczeństwo. T. 2, A. Barciak, E. Chojecka, S. Fertacz (red.), Katowice 2012, s. 550-551.

${ }^{14}$ J. Mariański, Godność ludzka - wartość ocalona? Studium socjopedagogiczne, Płock 2017, s. 117-118. 
Profile aksjologiczne jednostek, a w rezultacie całych zbiorowości, można w rozmaity sposób socjologicznie rekonstruować, co jest konsekwencją zarówno przyjętych założeń badawczych, jak również rozstrzygnięć aksjologicznych wpisanych w projekty badań. Dotyczą one zwłaszcza „apriorycznego" wskazania wartości uznawanych za społecznie istotne, to znaczy takie, które tworząc specyficzny pejzaż kulturowy badanej społeczności, pozwalają również na ukazanie jej relacji z szerszymi wymiarami życia społecznego, na przykład narodowymi czy cywilizacyjnymi. Z jednej więc strony w pytaniach kwestionariusza wywiadu naszych badań znalazły się zagadnienia skali akceptacji wartości uniwersalnych, do których można zaliczyć między innymi szczęście, zdrowie, własną rodzinę, a z drugiej - pytania o znaczenie „wartości regionalnych", związanych z wyróżniającymi oraz ważnymi dla kulturowych cech społeczności Górnego Śląska kwestiami identyfikacji narodowej czy regionalnej. Pytanie kwestionariusza wywiadu umożliwiało deklarację uznania wybranych przykładów wartości z zaznaczeniem, że mają one dla respondenta: „duże znaczenie”, „średnie znaczenie”, „małe znaczenie” lub „nie mają znaczenia”. Respondenci mogli też wybrać odpowiedź: „nie dotyczy”. $\mathrm{W}$ tabeli 2 przedstawiam dane odnoszące się do wyborów podkreślających "duże znaczenie” wskazanych wartości, przyjmując że jest to wyraz zdecydowanych deklaracji przypisujących poszczególnym wartościom istotną rolę w praktykowanych stylach życia. Przypisanie wskazanym wartościom „dużego znaczenia w swoim życiu" można łączyć z podejmowanymi działaniami na rzecz nie tylko ich deklaratywnego uznawania, ale także wpisywania w praktyki zachowań i działań społecznych.

Szczegółowy rozkład danych pozwolił pogrupować analizowane przykłady wartości na pięć obszarów określonych przeze mnie jako wartości prymarne, dominujące, nieobojętne, drugorzędne i marginalne.

Tabela 2.Hierarchia uznawanych wartości

\begin{tabular}{|c|c|c|}
\hline Proszę powiedzieć, jakie znaczenia maja dla P. ? & $\begin{array}{c}\text { „Duże znaczenie” } \\
\text { w l.b. }\end{array}$ & $\mathrm{W} \%$ \\
\hline \multicolumn{3}{|l|}{ Prymarne } \\
\hline Zdrowie & 295 & 91.33 \\
\hline Własna rodzina & 288 & 89.16 \\
\hline Szczęście & 286 & 88.54 \\
\hline Spokojne życie & 281 & 86.99 \\
\hline \multicolumn{3}{|l|}{ Dominujące } \\
\hline Przyjaciele & 237 & 73.37 \\
\hline Dzieci & 235 & 72.76 \\
\hline
\end{tabular}




\begin{tabular}{|l|c|c|}
\hline \multicolumn{1}{|c|}{ Proszę powiedzieć, jakie znaczenia maja dla P. ? } & $\begin{array}{c}\text { "Duże znaczenie” } \\
\text { w l.b. }\end{array}$ & W \% \\
\hline Realizacja własnych zainteresowań & 223 & 69.04 \\
\hline Czas wolny i wypoczynek & 219 & 67.80 \\
\hline \multicolumn{1}{|c|}{ Nieobojętne } & 168 & 52.01 \\
\hline Przynależność do narodu polskiego & 166 & 51.39 \\
\hline Uznanie, szacunek ludzi & 154 & 47.67 \\
\hline Pomaganie innym Drugorzędne & 146 & 45.20 \\
\hline Praca zawodowa & & \\
\hline & 124 & 38.39 \\
\hline Wiara religijna & 104 & 32.20 \\
\hline Bycie Górnoślązakiem & 88 & 27.24 \\
\hline Majątek, dostatnie życie & 75 & 23.22 \\
\hline Zamieszkiwanie w w Zabrzu & & \\
\hline \multicolumn{1}{|c|}{ Marginalne } & 38 & 11.76 \\
\hline Uczestnictwo w stowarzyszeniach, wolontariat & 13 & 4.02 \\
\hline Udział w polityce, życiu publicznym (władza, kariera) & & \\
\hline
\end{tabular}

Żródło: badania własne, prowadzone wśród mieszkańców Zabrza

Świat wartości prymarnych ma wymiar uniwersalny, czyli taki, który z łatwością można odnaleźć w innych środowiskach społecznych czy kręgach kulturowych. Definiuje model godnego życia oraz profil osobowości społecznej jednostek skoncentrowany na autoregulacjach aksjologicznych dotyczących fundamentalnych wymiarów osobistego życia, odnoszących się zarówno do kondycji biologicznej jak i duchowej, godnościowej. Życie spokojne, w dobrym zdrowiu, szczęśliwe oraz w otoczeniu własnej rodziny tworzy najczęściej wskazywaną konstelację wartości uznawanych i zapewne też odczuwanych ${ }^{15}$, którym przypisany jest status oczekiwań i które tworzą normatywny model godnego życia. Nawet jeśli praktyki codzienności dramatycznie niekiedy odbiegają od nakreślonej wizji oczekiwań godnego życia, to i tak wyróżniona konstelacja wartości tworzy - w świadomości społecznej - kanon aksjologicznych oczekiwań, swoisty symboliczny układ porównawczego i normatywnego odniesienia,

${ }^{15}$ Nawiązuję tu do wprowadzonego przez Stanisława Ossowskiego rozróżnienia na wartości uznawane oraz wartości odczuwane. S. Ossowski, Konflikty niewspótmiernych skal wartości, [w]: tenże, Z zagadnień psychologii społecznej, Dzieła. T. 3, Warszawa 1967, s. 71. Zob. także: W. Świątkiewicz, Integracja kulturowa i jej społeczne uwarunkowania, Katowice 1987, s. 63-64. 
pozwalający na ocenę warunków własnego życia, doświadczonych deficytów oraz na nakreślenie kierunku działań na rzecz polepszenia jego kondycji.

Wśród wartości prymarnych najbardziej akceptowaną wartością jest zdrowie, a najmniej - spokojne życie. Rekonstruowana hierarchia uznawanych wartości jest odzwierciedleniem kierunku współczesnych przemian kulturowych silnie akcentujących aksjologiczne zorientowanie na indywidualne losy jednostki (zdrowie, szczęście, spokojne życie) z podkreśleniem znaczenia relacji wspólnotowych, których sygnaturą jest „własna rodziny”, uznawana jako prymarna wartość. Wyeksponowanie zdrowia, jako wartości indywidualnej, na pierwszym miejscu w hierarchii uznawanych wartości może być traktowane jako rezultat internalizacji sygnalizowanych wyżej przemian kulturowych, natomiast silne akcentowanie znaczenia wartości rodziny, czyli wartości wspólnotowych, jest wyrazem obecności tradycji kulturowych, które w polskim społeczeństwie skupiają się wokół społeczno-integracyjnych funkcji rodziny i jej pierwszorzędnego znaczenia. Na podobną strukturę wartości prymarnych wskazują także najnowsze badania CBOS, które w perspektywie czasowej 2008-2019 podkreślają stabilność lub nawet dynamikę przyrostu znaczenia szczęścia rodzinnego, własnego zdrowia oraz spokojnego życia ${ }^{16}$. Można więc uznać, że orientacje na wartości prymarne wśród mieszkańców Zabrza wpisują się w przestrzeń aksjologiczną charakterystyczną dla całego polskiego społeczeństwa.

Wysokim poziomem akceptacji charakteryzują się także wartości opisane w naszej interpretacji określeniem „dominujące”. Są one traktowane jako mające duże znacznie wśród 68\%-73\% respondentów. Zalicza się do nich relacje przyjaźni z innymi ludźmi, możliwość realizacji własnych zainteresowań, wypoczynek i czas wolny, a także posiadanie dzieci. W wyróżnionej konstelacji wartości dostrzegamy swoiste bilansowanie się wartości jednostkowych i wspólnotowych, z wyraźniejszym jednak zaakcentowaniem wartości odnoszących się do relacji społecznych, których ilustracją jest „posiadanie” przyjaciół i dzieci. Podobnie jak w przypadku wartości prymarnych, wymienione wartości wspólnotowe są refleksem polskich tradycji kulturowych, które - jak to pokazuje wiele badań socjologicznych - są silnie eksponowane w hierarchii uznawanych wartości, choć dawniej ich usytuowanie w porządku hierarchicznym było zwykle wyższe niż w przypadku naszych badań. Znana jest w literaturze socjologicznej teza prof. Stefana Nowaka z końca lat 70. XX wieku o „próżni socjologicznej”, która wskazywała na dominujące wówczas znaczenie rodziny i kręgów przyjaciół oraz wspólnoty narodowej jako wiodącego układu wartości, charakteryzującego

${ }^{16}$ R. Boguszewski, CBOS, Komunikat. Rodzina - jej znaczenie i rozumienie, nr 22/2019, online; https://cbos.pl/SPISKOM.POL/2019/K_022_19.PDF [dostęp: 4 sierpnia 2020]. Zob. też M. Feliksiak, Sens życia - wczoraj i dziś, CBOS. Komunikat z badań, nr 41/2017, online: https://www.cbos.pl/ SPISKOM.POL/2017/K_041_17.PDF [dostęp: 4 sierpnia 2020]. 
ówczesne polskie społeczeństwo ${ }^{17}$. Tylko $\mathrm{z}$ pewnym przybliżeniem możemy konkludować, że referowane przeze mnie wyniki badań prowadzonych wśród mieszkańców Zabrza wskazują na kierunki przemian świata wartości w polskim społeczeństwie w końcu drugiej dekady XXI wieku, czyli mniej więcej w perspektywie pięćdziesięciu ostatnich lat. Ilustracją tych przemian jest także wysokie notowanie w hierarchii wartości mających „duże znaczenie” wartości indywidualnych dotyczących realizacji własnych zainteresowań oraz akcentujących wartość czasu wolnego i wypoczynku.

Niższą frekwencją wskazań charakteryzują się wartości określane jako nieobojętne, czyli takie, które ze względu na skalę akceptacji ich znaczenia w życiu indywidualnym są społecznie widoczne, ale nie przypisuje się im znaczenia dominującego lub prymarnego. Nadaje im duże znaczenie w swoim życiu $45 \%-52 \%$ respondentów. Tu na pierwszym miejscu znajdują się wartości korelujące z afiliacją do narodu polskiego. Specyfiką kulturową Górnego Śląska są relacje przenikania, dopełniania, obojętności, a niekiedy wykluczania polskiej i górnośląskiej wspólnoty kulturowej ${ }^{18}$. Zabrze, w którym przeprowadzane były badania terenowe, jest miastem, gdzie wielokulturowość oraz wyrastające stąd problemy relacji społecznych przejawiają się w praktykach życia codziennego i bywają kryteriami oceniania, integracji lub wykluczania, co uwidacznia się zarówno w relacjach sąsiedzkich, rodzinnych, prywatnych, jak i przenika w sfery życia instytucjonalnego; gospodarczego, politycznego czy kulturalnego, a nawet religijnego. Dlatego też w pytaniach kwestionariusza wywiadu uwzględniono przynajmniej dwa znaczące odniesienia do wspólnot kulturowych: polskiej i górnośląskiej. Pominięto, że względu na kryterium liczebności mieszkańców miasta, wspólnotę kultury niemieckiej, ale także ukraińskiej, romskiej, etc. Przypisanie „dużego znaczenia” traktowanej jako wartość przynależności do narodu polskiego przez 52\% respondentów jest ilustracją pewnego typu men-

${ }^{17}$ S. Nowak, System wartości społeczeństwa polskiego, „Studia Socjologiczne” 1979, nr 4, s. 156-173.

${ }^{18}$ Ilustracją złożonej sytuacji relacji kulturowych na Śląsku jest miedzy innymi książka Marii Szmeji pt. Śląsk - bez zmian? Ludzie, kultura i społeczność Śląska w perspektywie postkolonialnej, Kraków 2017. Odczytuję książkę jako projekt ideologiczny podporządkowany tezie o wszechobecnej krzywdzie, dyskryminacji, wykluczeniu, kolonizacji, marginalizacji, dominacji, postkolonizacji narodu polskiego wobec Ślązaków i wyszukiwaniu odpowiedzi na kierunkowe pytanie „dlaczego Ślązacy nie chcą być Polakami?” (s. 94). Ilustruje założenia tej perspektywy przywoływany cytat: „[....] trzeba definitywnie zerwać ze stereotypem śląskości jako bytu przynależnego do jednej, polskiej kultury. [....] [P]otrzebny jest powrót do korzeni. Odczytanie na nowo śląskości we współudziale samych Ślązaków, szukanie ich własnego rozumienia tego określenia" (s. 219) i konieczności budowania nowej narodowej tożsamości, bo „dla Śląska miotanie się między polskością i niemieckością jest uciążliwe”. „[...] [N]aród potrzebuje przestrzeni fizycznej i społecznej, a tego w Polsce Ślązakom brakuje” (s. 248). Zwłaszcza ta ostatnia teza o „przestrzeni fizycznej i społecznej”, która jest potrzebna dla realizacji funkcji budowania narodu, a która rzekomo jest ograniczana, reglamentowana czy „zabierana” Ślązakom przez Polaków wskazuje na ideologiczny wymiar tej książki, nawiązujący do najgorszych doświadczeń XX wieku. 
talności społecznej, w której kwestie narodowe, przynależności do wspólnot kulturowych nie odgrywają najważniejszej roli, lecz przypisuje się im znaczenie nieobojętne albo drugorzędne, jak w przypadku afiliacji do kultury górnośląskiej. Dla porównania można dodać, że silną identyfikację z narodem polskim, co przez analogię można uznać za przypisanie wspólnocie narodowej jako wartości „dużego znaczenia”, w badaniach przeprowadzonych w Katowicach wskazało $67.7 \%$ badanych ${ }^{19}$, a w Sosnowcu $-62.3 \%{ }^{20}$. W takim kontekście porównawczym afiliacje do polskiej wspólnoty narodowej, postrzegane w kategoriach orientacji na wartości, są wśród mieszkańców Zabrza wyraźnie słabiej zadomowione w ich mentalności społecznej.

Obok przynależności do narodu polskiego, obszar wartości nieobojętnych tworzą także: uznanie i szacunek ludzi, pomoc udzielana innym oraz praca zawodowa. Dwie pierwsze wartości - uznanie i szacunek ludzi oraz pomoc udzielana innym - wzajemnie się dopełniają. Są to wartości, o które trzeba zabiegać, na które trzeba zasłużyć swoim postępowaniem, działaniem czy postawą, natomiast wskazana jako wartość pomoc udzielana innym jest podłożem, na którym może wyrastać szacunek i uznanie, jakim obdarzani są ludzie prospołeczni, otwarci na potrzeby innych, dostrzegający ich obecność i konieczność pomocy.

Wskazanie na pracę zawodową jako wartość posiadająca „duże znaczenie” jest $\mathrm{z}$ wielu względów oczywistością. Można jedynie podjąć refleksję nad usytuowaniem tej wartości w hierarchii uznawanych wartości. Charakterystyki cech kulturowych górnośląskiej regionalności zwykle wskazują na dominujące znaczenie konstelacji trzech wzajemnie dopełniających się wartości: pracy, rodziny i religijności. Są one zazwyczaj deklaratywnie sytuowane w górnych partiach hierarchii uznawanych wartości. ${ }^{21}$ Komentowane wyniki naszych badań zdają się wskazywać na pewne dekonstrukcje czy pęknięcia obrazu górnośląskiej tradycji kulturowej. Zachowaniu wysokiej pozycji wartości rodziny w przestrzeni regionalnej górnośląskiej kultury towarzyszy jednak widoczne obniżenie w hierarchii znaczenia pracy, a tym bardziej religijności, która jako uznawana wartość została zakwalifikowana do porządku wartości drugorzędnych.

Do grupy wartości drugorzędnych należą: wiara religijna, bycie Górnoślązakiem, majątek, dostatnie życie, zamieszkiwanie w Zabrzu. Na „duże znaczenie” wymienionych wartości w życiu wskazywało od 23\% do 38\% respondentów.

Zwracałem wyżej uwagę na stosunkowo niskie (jak na charakterystyki śląskiej kultury regionalnej) usytuowania wartości „wiary religijnej”. Duże znaczenie w swoim życiu przypisuje jej 38.39\%. badanych Na podstawie analizy odpowiedzi

19 W. Świątkiewicz, Wymiary identyfikacji społecznych, [w]: Katowice. Środowisko, dzieje kultura, język i społeczeństwo. T. 2, A. Barciak, E. Chojecka, S. Fertacz (red.), Katowice 2012, s. 531.

20 Tamże, s. 597.

${ }_{21}$ W. Świątkiewicz, Tradycja i wybór. Socjologiczne studium religijności na Górnym Śląsku, Katowice-Wrocław 1997; U. Swadźba, Śląski etos pracy: studium socjologiczne, Katowice 2001. 
na inne pytania zapisane w kwestionariuszu omawianych badań, które dotyczyły autodeklaracji wiary religijnej, można wnioskować, że za głęboko wierzących uznaje się $13.9 \%$, a za wierzących $-57.3 \%$. Blisko $7 \%$ badanych wskazuje na swoje niezdecydowanie w prawach religijnych, a 9.6\% jest religijnie obojętnych. Ponad 8\% respondentów określa siebie jako niewierzących, a 4\% nie udzieliło na pytanie odpowiedzi, co raczej powiększa odsetki osób deklarujących dystans do spraw religijnych lub niewierzących. Inaczej agregując dane, możemy wskazać, że nieznacznie więcej niż $71 \%$ badanych mieszkańców miasta autodefiniuje siebie jako osoby wierzące i głęboko wierzące. Jednak nie dla wszystkich tych osób wiara religijne posiada „duże znaczenie” w życiu, ponieważ postawę taką deklaruje „tylko” 38.39\% badanych. Można wnioskować, że zapewne część osób deklarujących się jako wierzące nie przypisuje swoim autodeklaracjom religijnym „bardzo ważnego” czy „dużego znaczenia” w praktykach życia codziennego i przyznaje im raczej funkcje ornamentacyjne lub traktuje jako etykiety religijno-kulturowych afiliacji społecznych.

Mniej niż jedna trzecia badanych (32.20\%) wskazuje na swoje silne identyfikacje z kulturą regionalną, deklarując że bycia Górnoślązakiem jest wartością i ma „duże znacznie”. Specyficzną cechą górnośląskiej kultury jest bardzo silna i wyraźnie społecznie widoczna identyfikacja z regionem Górnego Śląska jako uznawaną i odczuwaną wartością, która znajduje swoje odzwierciedlenie w postawach i działaniach społecznych ${ }^{22}$. Przyjmuje ona wiele kształtów, ale najbardziej widocznym $\mathrm{z}$ nich w codziennych praktykach językowych jest sposób autoidentyfikacji z przestrzenią zamieszkania, urodzenia czy pracy. „Urodziłem się na Śląsku”, „mieszkam na Śląsku”, „pracuję na Śląsku”, „jestem Ślązakiem” - to przykłady specyficznych określeń autoidentyfikacyjnych, które w przypadku mieszkańców innych regionów kulturowych Polski będą raczej opisywane nie tyle przez afiliacje do regionalnej kultury, ile poprzez wskazanie nazwy konkretnego miejsca urodzenia, zamieszkania czy pracy, np. „urodziłem się w Gdańsku”, „mieszkam w Warszawie”, „pracuję w Łodzi”, „jestem poznaniakiem”. Śląskość jest silnym kryterium identyfikacji społecznych, a więzi z kulturą regionalną w niektórych górnośląskich środowiskach są wyraźniejsze niż np. więzi narodowe. Zabrze jest społecznością miejską, w której widoczne są procesy przenikania, wykluczania, dystansu, obojętności lub niechęci, a nawet konfliktu różnych środowisk kulturowych tworzących tkankę współczesnego miasta. W pewnym stopniu procesy te mają swoje źródło w historii miasta, które - w części swoich obecnych dzielnic - zastało włączone w obręb państwa polskiego po II wojnie światowej, doświadczając bolesnych skutków „wielkiej historii" i ruchów migracyjnych, radykalnie zmieniających strukturę narodo-

${ }_{22}$ M.G. Gerlich, „My prawdziwi Górnoślązacy...”. Studium etnologiczne, Katowice-Warszawa 2010; J. Kijonka, Tożsamość współczesnych Górnoślązaków, Katowice 2015. 
wą, etniczną, klasową, a także religijną mieszkańców miasta. Różnorodność środowisk kulturowych i etnicznych zamieszkujących miasto była jego cechą także przed II wojną światową, ale po jej zakończeniu, w atmosferze pamięci o jej okrucieństwach, a potem w kontekście marksistowsko-leninowsko zideologizowanej polityki władz PRL-u wobec Górnego Śląska, różnorodność ta przybrała nowe wymiary obojętności, zadrażnień, konfliktów, żywiących się stereotypami i politycznymi czy gospodarczymi interesami. Identyfikacja ze Śląskiem jako regionem kulturowym, wyrażająca się poprzez określenie „jestem Górnoślązakiem”, jest współcześnie często traktowana jako sygnatura orientacji aksjologicznych, będących wyrazem afiliacji nie tylko kulturowych, ale także narodowych lub etnicznych (albo ich obu zarazem) ${ }^{23}$.

W deklarowanej przez mieszkańców Zabrza hierarchii wartości ponad 27\% osób uczestniczących w naszych badaniach wskazało na majątek i dostatnie życie jako wartość, która posiada „duże znaczenie” w ich życiu, co jest ilustracją orientacji na tzw. wartości materialistyczne. W świadomości mieszkańców Zabrza są one społecznie widzialne, ale nie stanowią wyróżniającej cechy kulturowej miejskiej społeczności, o czym świadczą również omawiane wyżej odpowiedzi na pytanie o projektowany sposób dysponowania większymi, dodatkowymi środkami finansowymi.

$\mathrm{Na}$ ostatnim miejscu, w hierarchii wartości drugorzędnych znajduje się ocena miejscowości zamieszkania. Nieco ponad jedna piąta mieszkańców Zabrza (23.22\%) ceni sobie fakt zamieszkiwania w tym mieście i uznaje, że jest to dla nich „duża wartość”, która zapewne wyraża się w postawie identyfikacji z miastem i jego mieszkańcami. Porównując z innymi miastami województwa śląskiego, na podobnie postawione pytanie odpowiedziało pozytywnie $44 \%$ mieszkańców Katowic ${ }^{24}$ oraz 23\% mieszkańców Sosnowca ${ }^{25}$. Poziom identyfikacji z miastem i jego mieszkańcami jest wskaźnikiem zadomowienia w przestrzeni miasta, jego historii i współczesności, a w konsekwencjach może przejawiać się w postawach aktywnego uczestnictwa w procesach miejskich lub też wycofaniem i dystansem traktującym miasto jako swoisty przypadek „nie-miejsca” ${ }^{26}$, czyli przestrzeni pustej znaczeniowo, ubogiej w relacje społeczne, może obojętnej, a nawet obcej. Za interesującą ilustrację tych procesów mogą posłużyć opinie zapisane w jednym ze współczesnych reportaży o Zabrzu:

${ }^{23}$ Ilustracją tych relacji mogą być wyniki Spisu Ludności z roku 2011, w którym 834 tys. obywateli Polski opowiedziało się za narodowością śląską, w tym 362 tys. wskazało tylko śląską narodowość, a 415 tys. podkreślało łącznie polską i śląską przynależność narodową.

24 W. Świątkiewicz, Wymiary identyfikacji społecznych, [w]: Katowice. Środowisko, dzieje kultura, język i społeczeństwo. T. 2, A. Barciak, E. Chojecka, S. Fertacz (red.), Katowice 2012, s. 531.

25 Tamże, s. 597.

26 M. Dymnicka, Od miejsca do niemiejsca, „Acta Universitatis Lodziensis. Folia Sociologica” 2011, nr 36, s. 35-52 
„Nie jesteśmy stąd, ale o Zabrzu dużo myślimy. Obydwoje z mężem jesteśmy filozofami, więc może dlatego. W każdym razie nieustannie próbujemy zrozumieć historie i tożsamość tego miejsca. Czujemy się tu tylko w gościach, ale nie przeszkadza nam to. W pewnym sensie wszyscy zabrzanie są gośćmi. Czasem chodzę po tym mieście i mam wrażenie, że jest trochę tak jak Atlantyda. Bo tu mieszkają ludzie, którzy nigdy nie myślą do końca „to jest nasze”. Skąd to wiem? To się czuje gdzieś w powietrzu. Jak pojechaliśmy na wakacje w okolice Słupska, też tak było. Po prostu czuć, że w tym domu kiedyś mieszkali inni ludzie, mówili w innym języku, mieli jakąś swoja historię. [...] Na co dzień bardzo tego nie widać, bo ta różnica pojawia się nieoczekiwanie, zwykle w pozornych drobnostkach. Na przykład rozmawiam z koleżanką, nagle dzwoni jej telefon, ktoś z rodziny i ona zaczyna rozmawiać po śląsku, czyli po domowemu, po czym odkłada słuchawkę, wraca do literackiej polszczyzny, ale ja już czuję, że przez moment dotknęłam innego świata, do którego nie mam na co dzień dostępu. Że jest obok mnie jakaś inna wspólnota języka. Albo niby gotuję na co dzień te wszystkie kluski śląskie, ale jak przychodzi wigilia, to nagle na stole pojawiają się potrawy ze Wschodu, bo w takich chwilach korzenie czuć najlepiej. Próbujemy się wszyscy jakoś w tym odnaleźć, ale momentami jest trudno"27.

Zdecydowanie najniższe znaczenie przypisywane jest aktywnościom społecznym oraz uczestnictwu w życiu politycznym. Wartości związane z tymi formami zaangażowania publicznego odgrywają w życiu mieszkańców miasta rolę marginalną. Uczestnictwo w stowarzyszeniach, wolontariat ujmowane z perspektywy wartości, która odgrywa „dużą rolę" w indywidualnych projektach życia deklaruje $11.8 \%$ badanych, a udział w polityce, życiu publicznym (władza, kariera polityczna) znajduje akceptację u $4 \%$ badanych. Niski poziom zaangażowania w sprawy obywatelskie, włączania się w różne formy wolontariatu, a tym bardziej marginalnie dostrzegana wartość zaangażowania politycznego są cechami charakteryzującymi całe polskie społeczeństwo. Na podobne konkluzje wskazują wyniki badań prowadzonych w Katowicach oraz w Sosnowcu ${ }^{28}$. Społeczność Zabrza nie jest od tych deficytów społeczeństwa obywatelskiego wolna. Przez dziesięciolecia czasów PRL-u kształtowała się mentalność społeczna rozróżniająca sfery życia prywatnego, zakorzenione we wspólnocie kultury narodowej, skupione zwłaszcza wokół rodziny jako wartości i kręgów przyjaciół, od sfer życia publicznego, naznaczanego marksistowsko-leninowską ideologią i reprezentującymi ją instytucjami państwowymi. Wykrystalizowały

${ }^{27}$ M. Rachid Chebab, Rodzina na 5 plus w dwóch odsłonach. Ulica Wolności. 10 reportaży o Zabrzu, Warszawa 2013, s. 123-124.

${ }_{28}$ Z Zagała, Kultura obywatelska mieszkańców miasta, [w:] Sosnowiec. Obraz miasta i jego dzieje. T. 2, A. Barciak, A. Jankowski (red.), Sosnowiec 2016, s. 588-592; Z. Zagała, Zorganizowanie społeczne, [w:] Katowice. Środowisko, dzieje kultura, język i społeczeństwo. T. 2, A. Barciak, E. Chojecka, S. Fertacz (red.), Katowice 2012, s. 519-527. 
się kryteria podziałów na „my” i „oni” oraz „swoich” i „obcych”. Sferami życia społecznego (publicznego), jak i prywatnego sterowały zasady opisane przez Jana Lutyńskiego w drugiej połowie lat 70. XX wieku jako „działania pozorne”29, regulujące przechodzenie między różnymi sferami życia społecznego publicznego i prywatnego, formalnego i nieformalnego, partyjnego (w rozumieniu komunistycznego) i niepartyjnego ${ }^{30}$ oraz usprawiedliwiające możliwe dysonanse w sferze osobowości społecznej jednostek. Za jeden z najistotniejszych problemów politycznych reform ustrojowych i przemian społecznych zapoczątkowanych w Polsce po roku 1989 można uznać przełamywanie obcości struktur państwowych i sfery życia publicznego. Procesy „oswajania władzy” nie są dokończone, a toczone w ostatnich latach walki polityczne między ugrupowaniami partyjnymi, instrumentalizującymi wartości wpólnototwórcze, zdają się reanimować podziały polityczne okresu „słusznie minionego” i często w zasobach skompromitowanej ideologii poszukują argumentów i kryteriów ocen. Partyjne spory o polityczne wartości wspólnoty państwowej oraz o prawo do ich legitymizacji i reprezentowania nie sprzyjają budowaniu w mentalności społecznej ani pozytywnemu wartościowaniu aktywności w życiu publicznym, ani przychylnym ocenom politycznego zaangażowania.

\section{Konkluzja}

Wiele czynników - historycznych i współczesnych, kulturowych i politycznych - determinuje czy modeluje obraz „obywatela miasta”, możliwy do rekonstrukcji na podstawie przeprowadzonych badań. Jego najbardziej widoczną cechą jest aksjologiczny dystans, a może nawet przepaść między wartościami prymarnymi a marginalnymi. Jej miarą są różnice w odsetkach charakteryzujących wartości prymarne i marginalne, które w przypadku kobiet w odniesieniu do wartości zdrowia oraz udziału w polityce wynoszą prawie 92 punkty, a wśród mężczyzn - 83.8 punktów procentowych. Towłaśnie aksjologiczny dystans czy przepaść współtworzą profil aksjologiczny mieszkańców miasta, jego kultury oraz zapewne warunkują i ukierunkowują perspektywy rozwoju miejskiej społeczności.

Zdrowie, własna rodzina, szczęście i spokojne życie to wartości, którym przypisuje się największe znaczenie w projektach indywidualnego życia. Są one przedmiotem marzeń, zatroskania, nieustannych porażek i sukcesów na drogach ich praktykowania. Są normatywnym modelem, drogowskazem na-

29 J. Lutyński, Działania pozorne, „Kultura i Społeczeństwo” 1977, nr 21, s. 69-78.

30 Dychotomia „partyjny i niepartyjny” to jedno z podstawowych kryteriów podziałów społecznych w czasach PRL-u, bogata pojemnością semantyczną obydwu kategorii najogólniej odsyłających do postawy wobec marksistowsko-leninowskiej ideologii sterującej strukturami państwa i życia publicznego. 
dziei, pozwalającym każdorazowe niepowodzenia czy deficyty usprawiedliwiać w perspektywie kolejnych zmagań podejmowanych w celu osiągnięcia życiowej stabilizacji. Ich obecność w naszej codzienności wydaje się tak oczywista, że wpisane w zwyczajowe pozdrowienia czy składane życzenia - wydają się być niekiedy drażniącym, pozbawionym głębszej refleksyjności rytualnym i pustym znaczeniowo zachowaniem, które zagubiło swoje rzeczywiste aksjologiczne odniesienia. Korektę artykułu redaguję w początku kwietnia roku 2020, w czasie gdy świat pogrążyła pandemia wirusa sprawiającego, że człowiek dla drugiego człowieka jest niewidzialnym, ale potencjalnie realnym śmiertelnym zagrożeniem. W błyskawicznym tempie sygnaturą społeczeństwa czasu zarazy stały się zamknięte drzwi, egzystencjalne podziały i aksjologiczne zagubienie. Trudno oprzeć się refleksji nad trafnością najważniejszych wyborów życiowych, wśród których to właśnie zdrowie - tym bardziej w czasach zarazy - staje się deficytowym fundamentem nie tylko biologicznego, ale również społeczno-kulturowego, religijnego czy gospodarczego spokojnego życia w szczęściu i w relacjach rodzinnych. Znaczenie tych wartości oraz ich wagę w życiu jednostkowym i całych zbiorowości uświadamiamy sobie wówczas, gdy ich brakuje, gdy podlegają zagrożeniu, a nawet unicestwieniu. W tym kontekście niezwykle dramatycznie brzmią słowa papieża Franciszka wypowiedziane w bezprecedensowych czasach i w bezprecedensowej formie, na opustoszałym placu św. Piotra:

„Czemu tak bojaźliwi jesteście? Jakże wam brak wiary?”. Panie, dziś wieczorem Twoje Słowo uderza i dotyka nas wszystkich. W tym naszym świecie, który kochasz bardziej niż my, ruszyliśmy naprzód na pełnych obrotach, czując się silnymi i zdolnymi do wszystkiego. Chciwi zysku, daliśmy się pochłonąć rzeczom i oszołomić pośpiechem. Nie zatrzymaliśmy się wobec Twoich wezwań, nie obudziliśmy się w obliczu wojen i planetarnych niesprawiedliwości, nie słuchaliśmy wołania ubogich i naszej poważnie chorej planety. Nadal byliśmy niewzruszeni, myśląc, że zawsze będziemy zdrowi w chorym świecie [podkr. WŚ]. Teraz, gdy jesteśmy na wzburzonym morzu, błagamy cię: „Zbudź się Panie!”31.

Zdrowie jako wartość egzystencjalna nie może się dać pochłonąć rzeczom i oszołomić pospiechom, bo wówczas i ono straci swój sens.

Mozaikę pożądanych i zapewne w jakimś stopniu praktykowanych wartości współtworzą zabieganie o szacunek i uznanie u ludzi, połączone z potrzebą pomagania i prosposłeczności, nieprzybierającej jednak form zrzeszeniowych. $\mathrm{W}$ hierachii deklarowanych wartości współwystępują one z relatywnie wysokim znaczeniem przypisywanym afiliacjom do polskiej kultury narodowej. Naszymi badaniami empirycznymi nie obejmowaliśmy praktyk codzienności, ale - w na-

${ }^{31}$ Rozważania Papieża Franciszka podczas modlitwy na Placu św. Piotra o ustanie pandemii, online: https://www.gosc.pl/doc/6233401.Mocne-slowa-Franciszka-podczas-modlitwy-o-ustanie-pandemii [dostęp: 27 marca 2020]. 
wiązaniu do sytuacji czasu zarazy - możemy wskazać wiele podejmowanych działań aktualizujących deklarowane wartości w inicjatywach wsparcia służb medycznych, osób starszych, dzieci, bezdomnych i bezrobotnych, w sferze upowszechniania kultury i organizacji czasu wolnego ${ }^{32}$, etc. Mniejsze znaczenie przypisywane jest wartościom religijnym, materialnym, identyfikacjom z Zabrzem jako przestrzenią miejsca zamieszkania czy kulturą regionalną Górnego Śląska, najniżej cenione jest zaangażowanie w politykę i działania stowarzyszeniowe.

Można jeszcze inaczej spojrzeć na świat wartości mieszkańców miasta. Cechuje go bowiem nie tylko wspomniany wyżej dystans między wartościami prymarnymi i marginalnymi, ale jego własnością jest również większa koncentracja wokół osobistych wymiarów życia, może większy indywidualizm, zapatrzenie we własne potrzeby. Będące udziałem całego naszego społeczeństwa i świata globalnego doświadczenia zatrzymywania społeczeństwa, zamykania gospodarki, radykalnego ograniczania bezpośrednich relacji społecznych, samotności i osamotnienia, dostrzeżenie konieczności zachowania funkcjonalnych reguł i struktur tworzących podstawy życia społecznego, bezwzględności $\mathrm{w}$ przestrzeganiu wzajemnych zobowiązań i zasad stojących na straży ładu społecznego, będzie z pewnością wpływało na modyfikację hierarchii uznawanych i odczuwanych wartości. Być może w większym stopniu akcentowane będzie zorientowanie na wartości wspólnotowe, łączące dar uwolnionego od stereotypów dostrzegania warunków życia społecznego i praktykowanych stylów życia z wyczuleniem na świat najwyższych wartości ludzkich - inwariantnych, uniwersalnych, o ponadkulturowym znaczeniu.

\section{Bibliografia}

Barciak A., Chojecka E., Fertacz S. (red.), Katowice. Środowisko, dzieje, kultura, język i społeczeństwo. T. 1-2, Katowice 2012.

Barciak A., Jankowski A. T. (red), Sosnowiec. Obraz miasta i jego dzieje. T. 1-2, Sosnowiec 2016. Afeltowicz Ł., Gądecki J., Olechnicki K., Szlendak T., Wróblewski M., Efekt Bilbao / kult cargo. Nowe instytucje kultury w Polsce, Elbląg 2018.

Berger P. L., Luckmann T., Społeczne tworzenie rzeczywistości, Warszawa 1983.

Bogunia-Borowska M. (red), Fundamenty dobrego społeczeństwa. Wartości, Kraków 2015.

Burzyński J., Nowoczesny katowiczanin, w: Katowice. Środowisko, dzieje, kultura, język i społeczeństwo. T. 2, A. Barciak, E. Chojecka, S. Fertacz (red.), Katowice 2012, s. 547-554

${ }^{32}$ Filharmonicy Zabrzańscy „To My!”. W trudnym czasie pandemii grupa muzyków Filharmonii Zabrzańskiej wpadła na pomysł zdalnego nagrania utworu. Muzyk orkiestry, a zarazem kompozytor i aranżer, Wiesław Świderski, skomponował specjalnie na tę okazję utwór „,To My!”. Projekt ten jest wyrazem podziękowania i solidarności z wszystkimi, którzy walczą z epidemią - lekarzom, pielęgniarkom oraz służbom dzielnie ratujących nas wszystkich. Filharmonicy Zabrzańscy „To My”, online: https://www.gosc.pl/doc/6240545.Filharmonicy-Zabrzanscy-To-My [dostęp: 3 kwietnia 2020]. 
Chebab M. R., Rodzina na 5 plus w dwóch odsłonach. Ulica Wolności. 10 reportaży o Zabrzu, Warszawa 2013.

Czarnowski S., Kultura. Dzieła. T. 1, Warszawa 1956.

Górny A., Czas wolny, w: Sosnowiec. Obraz miasta i jego dzieje. T. 2, A. Barciak, A. T. Jankowski (red.), Sosnowiec 2016, s. 571-575.

Górny A., Czas wolny, w: Katowice. Środowisko, dzieje, kultura, język i społeczeństwo. T. 2, A. Barciak, E. Chojecka, S. Fertacz (red.), Katowice 2012, s. 506-510.

Gerlich M.G., „My prawdziwi Górnoślązacy...." Studium etnologiczne, Katowice-Warszawa 2010.

Dymnicka M., Od miejsca do niemiejsca, „Acta Universitatis Lodziensis. Folia Sociologica” 36, 2011, s. 35-52.

Ingarden R., Książeczka o człowieku, Kraków 1987.

Lutyński J., Działania pozorne, „Kultura i Społeczeństwo”, 1997, nr 2, s. 69-78.

Kasperek A., Praca i wzory konsumpcji, w: Katowice. Środowisko, dzieje, kultura, język i społeczeństwo. T. 2 A. Barciak, E. Chojecka, S. Fertacz (red.), Katowice 2012, s. 501- 506.

Kijonka J., Praca i wzory konsumpcji, w: Sosnowiec. Obraz miasta i jego dzieje. T. 2 A. Barciak, A. T. Jankowski (red.), Sosnowiec 2016, s. 567-571.

Kijonka J., Tożsamość współczesnych Górnoślązaków, Katowice 2015.

Nowak S., System wartości społeczeństwa polskiego, ,'Studia Socjologiczne”, 1979, nr 4, s. 155-173.

Mariański J., Godność ludzka - wartość ocalona? Studium socjopedagogiczne, Płock 2017.

Mariański J., Socjologia i moralność. Czym jest i dokąd zmierza socjologia moralności, Toruń 2019.

Mariański J., Wartości uroczyste w świadomości maturzystów puławskich w latach 1994-2009-2016, „Uniwersyteckie Czasopismo Socjologiczne”, 2018, nr 2, s. 9-17.

Ossowski S., Konflikty niewspółmiernych skal wartości, w: tenże, Z zagadnień psychologii społecznej, Dzieła, T. 3., Warszawa 1967.

Rembierz M., Edukacja międzykulturowa jako ćwiczenie duchowe. Pedagogiczne wymiary kształtowania kultury duchowej i rozumienia wartości ponadkulturowych w kontekście zróżnicowania religijnego i pluralizmu światopoglądowego, „Edukacja Międzykulturowa”, 2018, nr 2, s. 90-129.

Stróżewski W., Ponadkulturowe wymiary dobra, prawdy i piękna, [w:] tenże, Logos, wartość, miłość, Kraków 2013, s. 361-388.

Swadźba U., Śląski etos pracy: studium socjologiczne, Katowice 2001.

Szmeja M., Śląsk - bez zmian? Ludzie, kultura i społeczność Śląska w perspektywie postkolonialnej, Kraków 2017.

Świątkiewicz W., Integracja kulturowa i jej społeczne uwarunkowania, Katowice 1987.

Świątkiewicz W., Religijność w przestrzeni kulturowej miasta, w: Sosnowiec. Obraz miasta i jego dzieje. T. 2, A. Barciak, A. T. Jankowski (red.), Sosnowiec 2016, s. 575-587.

Świątkiewicz W., Sacrum i tego światy, w: Katowice. Środowisko, dzieje, kultura, język i społeczeństwo. T. 2, A. Barciak, E. Chojecka, S. Fertacz (red.), Katowice 2012, s. 510-518

Świątkiewicz W., Tradycja i wybór. Socjologiczne studium religijności na Górnym Śląsku, Katowice-Wrocław 1997.

Świątkiewicz W., Wymiary identyfikacji społecznych, w: Katowice. Środowisko, dzieje, kultura, język i społeczeństwo. T. 2, A. Barciak, E. Chojecka, S. Fertacz (red.), Katowice 2012, s. 530-537.

Świątkiewicz W., Wymiary identyfikacji społecznych, w: Sosnowiec. Obraz miasta i jego dzieje.

T. 2, A. Barciak, A. T. Jankowski (red.), Sosnowiec 2016, s. 596-602.

Tyszka A., Kultura jest kultem wartości. Aksjologia społeczna - studia i szkice. Kęty 1999.

Zagała Z., Kultura obywatelska mieszkańców miasta, w: Sosnowiec. Obraz miasta i jego dzieje. T. 2, A. Barciak, A. T. Jankowski (red.), Sosnowiec 2016, s. 588-592.

Zagała Z., Zorganizowanie społeczne, w: Katowice. Środowisko, dzieje, kultura, język i społeczeństwo.

T. 2, A. Barciak, E. Chojecka, S. Fertacz (red.), Katowice 2012, s. 519-527. 


\section{Źródła internetowe}

Boguszewski R., CBOS, Komunikat. Rodzina - jej znaczenie i rozumienie, 2019, nr 22, online; https:// cbos.pl/SPISKOM.POL/2019/K_022_19.PDF [dostęp: 4 sierpnia 2020].

Dziedzina J., Cuda z Michigan, online: https://www.gosc.pl/doc/5727342.Cuda-z-Michigan [dostęp: 5 września 2019].

Efekt Bilbao online: https://archirama.muratorplus.pl/encyklopedia-architektury/efekt-bilbao,62_3345.html, [dostęp: 12 września 2019].

Feliksiak M., Sens życia - wCzoraj i dziś. CBOS. Komunikat z badań, 2017, nr 41, online: https:// www.cbos.pl/SPISKOM.POL/2017/K_041_17.PDF [dostęp: 4 sierpnia 2020].

Piecuch Cz., Stróżewski Władysław Antoni, w: Encyklopedia Filozofii Polskiej, A. Maryniarczyk (red.), online: http://www.ptta.pl/efp/pdf/s/strozewskiw.pdf [dostęp: 4 sierpnia 2020].

Papież Franciszek, Rozważania papieża Franciszka podczas modlitwy na Placu św. Piotra o ustanie pandemii, online: https://www.gosc.pl/doc/6233401.Mocne-slowa-Franciszka-podczas-modlitwy-o-ustanie-pandemii [dostęp: 27 marca 2020].

Filharmonicy Zabrzańscy „To My!”, online: https://www.gosc.pl/doc/6240545.Filharmonicy-Zabrzanscy-To-My / [dostęp: 3 kwietnia 2020].

\section{Światy wartości mieszkańców miasta. Na przykładzie badań socjologicznych w Zabrzu}

\section{Streszczenie}

Wartości należą do porządku kultury i stanowią fundamenty życia społecznego. Poprzez ich internalizację w postawy i zachowania oraz w praktyki życia społecznego ludzi, kształtują one profile kulturowe zarówno całych społeczności, jak i osobowości społecznych poszczególnych jednostek. Społeczności tworzą się wokół wspólnoty wartości i ze względu na nie przybierają konkretne postacie, takie jak na przykład naród, państwo, regiony kulturowe, miasta czy wspólnoty wyznaniowe. Profile kulturowe osobowości społecznej jednostek są konsekwencją internalizacji świata wartości w indywidualnie konstruowane i realizowane projekty życia społecznego.

Artykuł prezentuje rekonstrukcję systemów wartości mieszkańców miasta, na podstawie przeprowadzonych badań empirycznych. Skupia się na uwarunkowaniach materialnych deklarowanych orientacji na wartości oraz na hierachii wartości godnościowych. W hierachii uznawanych wartości wyodrębnione zostały wartości prymarne, dominujące, nieobojętne, drugorzędne oraz marginalne. Wiele czynników - historycznych i współczesnych, kulturowych i politycznych - determinuje czy modeluje obraz „obywatela miasta” możliwy do rekonstrukcji na podstawie przeprowadzonych badań. Jego najbardziej widoczną cechą jest aksjologiczny dystans, a może nawet przepaść między wartościami prymarnymi a marginalnymi.

Słowa kluczowe: wartości, hierarchia wartości, miasto, profil aksjologiczny mieszkańca miasta.

\section{A world of values of an urban inhabitants. The example of sociological research in Zabrze}

\section{Summary}

Values belong to the cultural order and constitute the foundations of social life. By internalizing them in attitudes and behaviors, in the practices of social life, people shape the cultural profiles 
of both entire communities and the social personalities of individuals. Communities are created around a community of values and because of this, they take specific forms, such as nations, states, cultural regions, cities or religious communities. Cultural profiles of individuals' social personalities are a consequence of the internalization of the world of values into individually constructed and implemented projects of social life.

The article presents the reconstruction of value systems of the city's inhabitants, based on empirical research. It focuses on material conditions of declared values orientation and the hierarchy of dignity values. In the hierarchy of recognized values, primary, dominant, indifferent, secondary and marginal values have been distinguished.

Many factors: historical and contemporary, cultural and political, determine whether it models the image of the "citizen of the cit"', which is possible to reconstruct based on the conducted research. Its most visible feature is the axiological distance and maybe even the gap between primary and marginal values.

Keywords: Values, hierarchy of values, city, axiological profile of an urban inhabitants. 